\title{
Aplikasi Game Cerita Rakyat Kodok Dan Harta Karun Berbasis Android
}

\author{
Made Swamahendra*, Dewa Putu Yudhi Ardiana, dan I Wayan Dharma Suryawan ${ }^{3}$ \\ ${ }^{123}$ STMIK STIKOM Indonesia \\ Jalan Tukad Pakerisan No.97, Denpasar 80225 \\ Corresponding author's e-mail: Madeswamahendra@gmail.com
}

\begin{abstract}
Abstrak - Indonesia kaya akan cerita rakyat yang mempunyai nilai kearifan lokal yang dapat digunakan untuk pembelajaran karakter. Terdapat fenomena kurangnya waktu orang tua untuk menceritakan cerita rakyat kepada anak. Penelitian ini bertujuan merancang dan membangun aplikasi game dengan tema cerita rakyat. Cerita rakyat yang digunakan dalam penelitian ini adalah kodok dan harta karun. Cerita tersebut mempunyai nilai selalu berbuat baik, tidak serakah, saling menyayangi dan kerja keras. Basis platform untuk aplikasi game adalah Android. Target pengguna dari aplikasi game ini adalah anak usia 5 sampai 10 tahun. Jenis game yang digunakan dalam penelitian ini adalah puzzle dan slide scrolling. Hasil penelitian ini menunjukkan aplikasi game telah berhasil dibangun. Hasil pengujian terhadap 30 orang menunjukkan sangat menarik untuk dimainkan.
\end{abstract}

Kata kunci: Game, Cerita Rakyat, Android.

\begin{abstract}
Indonesia is rich in folklore, which contains indigenous wisdom that may be used to develop character. There is a situation where parents are unable to recount traditional stories due to a lack of time. The purpose of this study is to design and develop a folklore-themed gaming application. The folklore that was consulted for this study is about frogs and treasure. The story teaches the importance of always doing what is right, of not being greedy, of loving one another and of working hard. The story of frogs and treasure teaches us the value of always doing good, not being greedy, loving each other and working hard. Android is the primary platform on which these gaming applications run. Children from 5 to 10 years old are the intended audience for this gaming application. Puzzles and slide-scrolling games were used in this study. The study's findings show that the gaming application was effectively developed. Thirty people were tested, and the findings indicated that it was a lot of fun to play.
\end{abstract}

Keywords: Game, Folklore, Android

\section{Pendahuluan}

Cerita rakyat mempunyai nilai kearifan lokal yang dapat digunakan dalam pembelajaran karakter pada anak. Penyampaian cerita rakyat kepada anak lebih banyak dilakukan orang tua dengan bercerita. Fenomena kurang diminati cerita rakyat oleh anak salah satunya disebabkan oleh kurangnya waktu orang tua untuk menyampaikan cerita [1]. Berdasarkan hasil wawancara dengan Made Taro, seorang maestro seni tradisi lisan yang telah berkecimpungan selama 46 tahun di dunia mendongeng ini mengatakan bahwa tradisi mendongeng di rumah tangga itu sudah jarang dan mungkin tidak ada lagi. Biasannya tradisi mendongeng itu masih di lakukan oleh orang terpelajar, orang intlelek dan punya waktu luang untuk mendongeng. Disadari oleh masyarakat maupun pemerintah khususnya Indonesia bahwa dongeng itu syarat dalam pendidikan karakter anak.

Terdapat banyak cerita rakyat yang ada di Indonesia. Salah satu cerita rakyat yang mengandung pesan moral adalah Kodok dan Harta Karun. Cerita ini memiliki pesan moral yaitu seperti halnya hukum karma phala, maka apa yang didapatkan adalah hasil dari apa yang diperbuat, tidak boleh serakah, selalu menyayangi orang tua dan apa yang diinginkan harus diwujudkan dengan cara kerja keras [2]. Pesan moral dalam cerita tersebut baik untuk menanamkan nilai-nilai selalu berbuat baik, tidak serakah, saling menyayangi dan kerja keras.

Salah satu upaya yang dapat dilakukan untuk membantu upaya penyampaian cerita rakyat tersebut ke anak adalah menggunakan teknologi[3]. Penyajian cerita rakyat dibuat dalam bentuk multimedia yang merupakan gabungan dari beberapa media yang dapat dinikmati oleh tidak hanya satu indera yang ada dimiliki manusia. Dengan banyaknya indera yang dapat digunakan diharapkan mampu meningkatkan minat terhadap cerita rakyat tersebut. Berdasarkan pemaparan tersebut, penelitian ini bertujuan menyajikan cerita rakyat tersebut dalam bentuk teknologi.

Teknologi yang dipilih untuk penelitian ini adalah video game atau disingkat game yang merujuk pada permainan menggunakan perangkat elektronik[4]. Pemilihan aplikasi game karena target dari aplikasi ini 
adalah anak usia 5 sampai 10 tahun. Cerita rakyat yang dikemas dalam bentuk game diharapkan dapat membuat penggunanya merasa senang. Game memiliki karakteristik menyenangkan [5][6]. Penelitian ini mengambangkan game dengan jenis puzzle dan slide scrolling.

Aplikasi game yang dirancang dan dibangun dalam penelitian ini diperuntukan untuk perangkat bergerak seperti smartphone dan tablet. Alasan dipilihnya perangkat tersebut karena banyak digunakan oleh pengguna sehingga diharapkan dapat menjangkau pengguna yang lebih luas [1][7]. Platform sistem operasi yang dipilih untuk rancang bangun aplikasi game ini adalah Android. Pemilihan Android karena banyak digunakan pada perangkat bergerak yang ada di Indonesia.

\section{Tinjauan Pustaka}

\subsection{Game}

Video Game atau sering disingkat Game merujuk pada permainan yang dimainkan menggunakan pernagkat elektronik. Game merupakan suatu kegiatan yang mempunyai aturan, konflik, tujuan serta berbentuk seni [8]. Terdapat karakteristik dari game[9]:

1. Simulasi berbasis aturan.

2. Responsif.

3. Menantang.

4. Kumulatif.

5. Membuat ingin memainkannya lagi

2.2. Cerita Kodok dan Harta Karun

Kisah Kodok dan Harta Karun ini menceritakan tentang seekor kodok tua yang memiliki dua anak, yang bernama Kendul dan Kendil. Sifat kedua anak itu memang sangat berbeda. Kendil sangat malas dan tidak pernah mengurus ayahnya. Lain kakaknya, Kendul. Ia selalu menolong ayahnya. Cerita ini memiliki pesan moral yaitu seperti halnya hukum karma phala, maka apa yang kita dapatkan adalah hasil dari apa yang kita perbuat, kita tidak boleh serakah, selalu menyayangi orang tua dan apa yang kita inginkan harus diwujudkan dengan cara kerja keras [2].

2.3. Android

Android merupakan platform yang dikembangkan oleh Google yang diperuntukkan untuk ponsel cerdas dan perangkat bergerak lainnya [10]. Pada awalnya Android dikembangkan oleh Android Inc yang didukung secara finansial oleh Google[11]. Selanjutnya Google membelinya pada tahun 2005 dan dirilis secara resmi pada tahun 2007 [12].

\section{Metode Penelitian}

Penelitian ini menggunakan metode software development life cycle (SDLC) tradisional dengan lima tahapan yaitu merencanakan, menganalisa, merancang, membangun dan menguji . Pada tahapan merencanakan kegiatan yang dilakukan adalah menentukan topik permasalahan dan mengumpulkan data. Data yang dikumpulkan melalui wawancara dan kepustakaan. Wawancara dilakukan dengan Made Taro dan kepustakaan dilakukan dengan mengumpulkan referensi terkait cerita rakyat.

Data yang telah terkumpul selanjutnya dianalisa pada tahapan menganalisa. Tahapan menganalisa melakukan analisa kebutuhan yang diperlukan untuk pembuatan aplikasi game dan menghasilkan sebuah rekomendasi untuk tahapan selanjutnya. Rekomendasi dari tahapan menganalisa digunakan sebagai pedoman untuk menentukan rancangan dari aplikasi game Tahapan merancang menentukan ilustrasi karakter, teks (tipografi), warna, audio yang akan digunakan dalam aplikasi game serta merancang storyboard game. Tahapan merancang menghasilkan sebuah rancangan yang akan diwujudkan pada tahapan selanjutnya.

Tapahan membangun merupakan tahapan perwujudan dari rancangan yang telah ditentukan dari tahapan sebelumnya. Aktivitas yang dilakukan dalam tahapan ini yaitu membuat aset, membuat audio narasi dan melakukan pemrograman aplikasi game dalam format Android. Setelah aplikasi diwujudkan selanjutnya dilakukan pengujian kepada 30 orang responden yang berusia 5 sampai 10 tahun. Berikut merupakan tahapan pengembangan aplikasi game: 


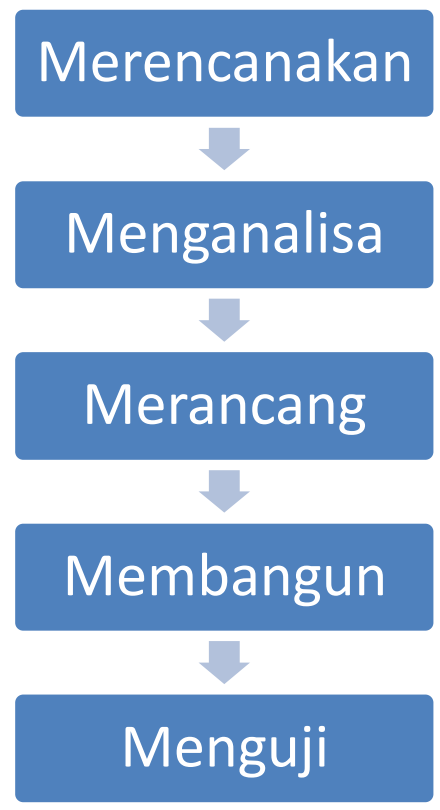

Gambar 1. Tahapan Pengembangan Aplikasi Game

\section{Hasil dan Pembahasan}

Penelitian ini menghasilkan aplikasi game yang dapat dijalankan pada perangkat bergerak dengan sistem operasi Android. Berikut merupakan tampilan dari aplikasi ketika dijalankan pada perangkat. Pada gambar 2 dapat ditampilkan tampilan awal dari aplikasi game terdapat tampilan gambar dan pengguna wajib menekan layar untuk menuju tampilan selanjutnya.

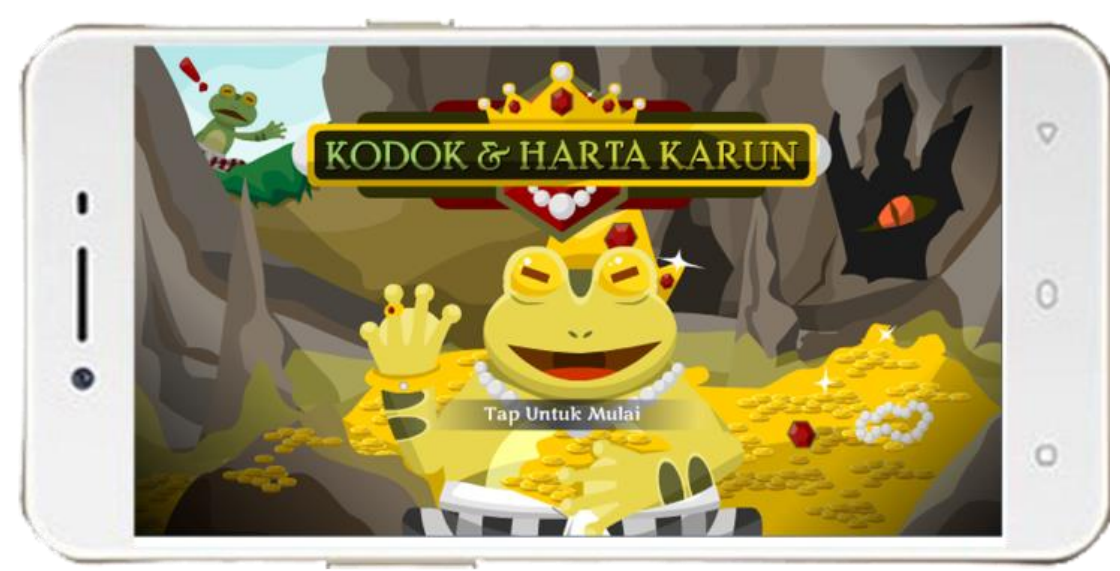

Gambar 2. Tampilan Awal Aplikasi Game

Setelah pengguna menekan tampilna awal aplikasi maka pengguna akan diberikan tampilan menu utama yang berisi tombol yang menuju bagian cerita, main dan tentang aplikasi. Pada tampilan menu awal terdapat tombol untuk menghentikan suara latar dan keluar dari aplikasi. Icon untuk bagian menuju main pada awalnya akan terkunci dan untuk membukanya pengguna harus menyelesaikan bagian cerita terlebih dahulu. Tampilan menu utama dapat dilihat pada gambar 3 . 


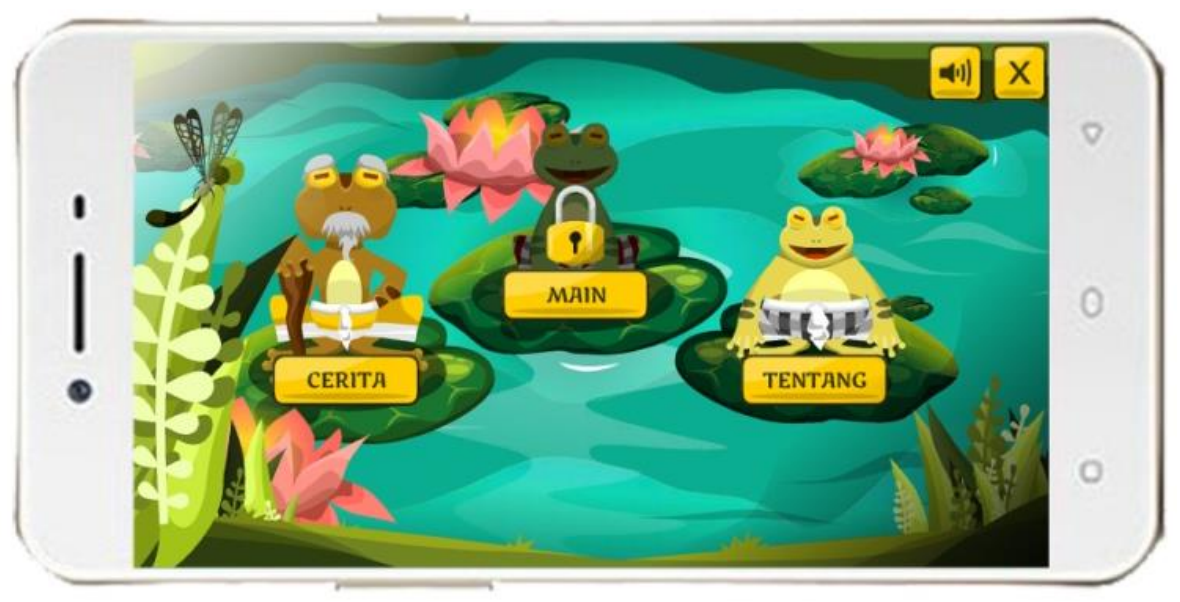

Gambar 3. Tampilan Menu Utama

Bagian cerita menampilkan cerita rakyat kodok dan harta karun. Pada bagian ini pengguna dapat menyaksikan slide cerita disertai dengan audio dan teks dari narasi cerita. Terdapat tombol untuk kembali ke menu awal, menghentikan suara latar dengan menlanjutkan ke slide selanjutnya. Bagian ini dapat dilihat pada gambar 4.

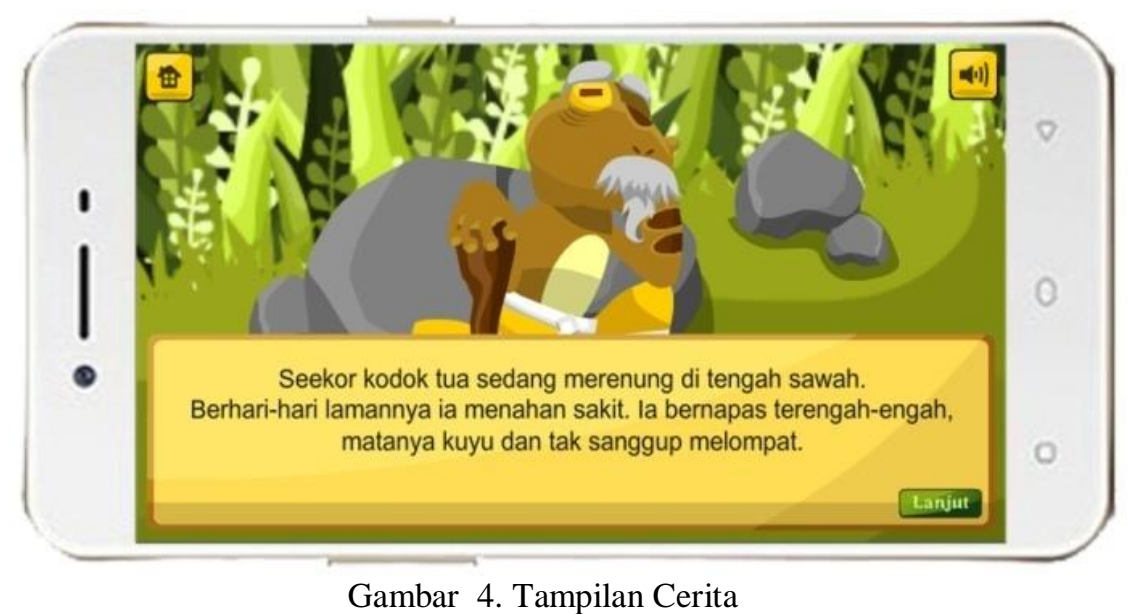

Pada akhir bagian cerita terdapat bagian pesan moral yang menceritakan pesan moral dari cerita rakyat kodok dan harta karun. Pada bagian ini terdapat tombol tamat yang akan menuju tampilan menu utama sekaligus membuka kunci dari bagian permainan. Bagian pesan moral dapat dilihat pada gambar 5. 


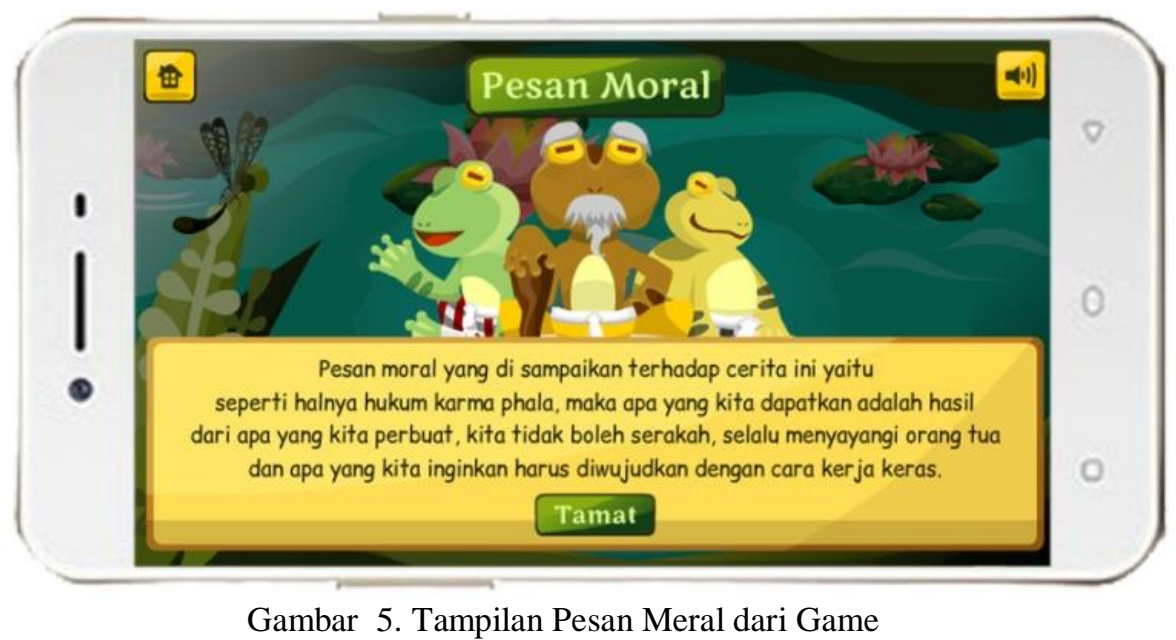

Pengguna dapat memilih bagian permainan dengan memilih icon permainan pada tampilan menu utama. Terdapat dua macam permainan pada bagian main, yaitu permainan puzzle dan slide scrolling. Tampilan pada bagian main dapat dilihat pada gambar 6.

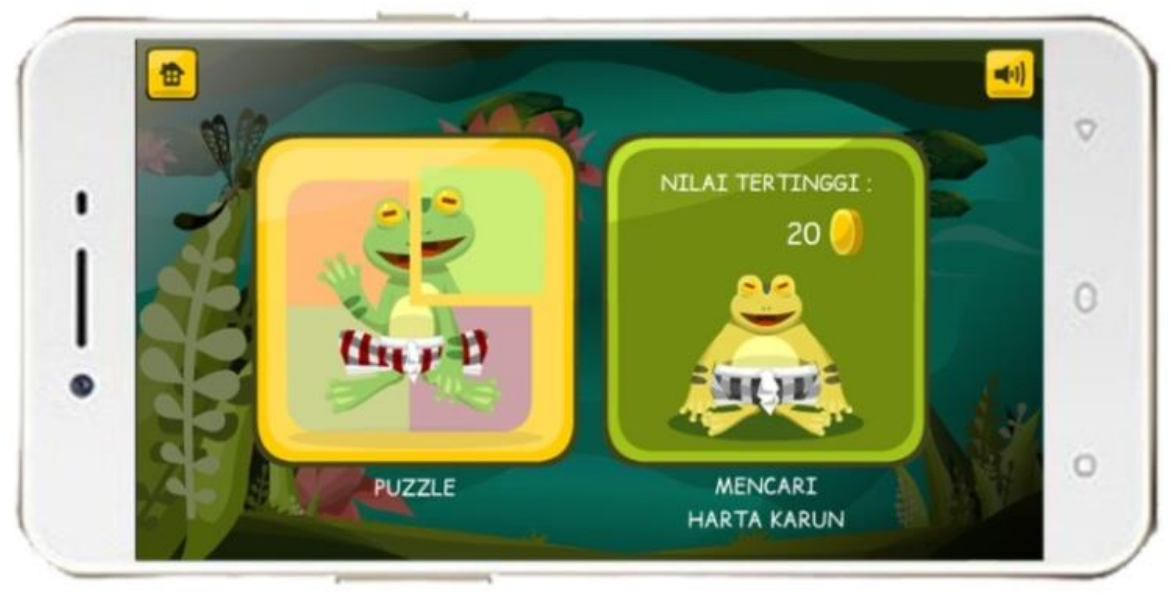

Gambar 6. Tampilan Bagian Main

Terdapat empat tingkat pada bagian permainan puzzle. Makin meningkat tingkat maka makin meningkat jumlah kepingan puzzle yang ada. Tampilan permainan Puzzle dapat dilihat pada gambar 7. Tampilan tingkat dapat dilhat pada gambar 8, 9, 10 dan 11. 


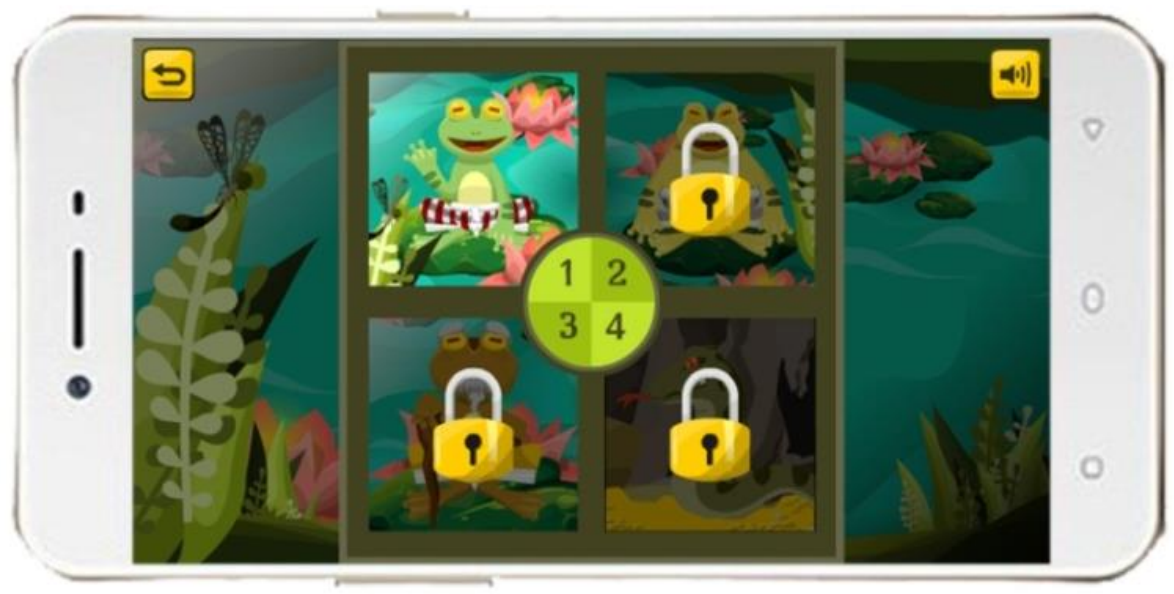

Gambar 7. Tampilan Permainan Puzzle

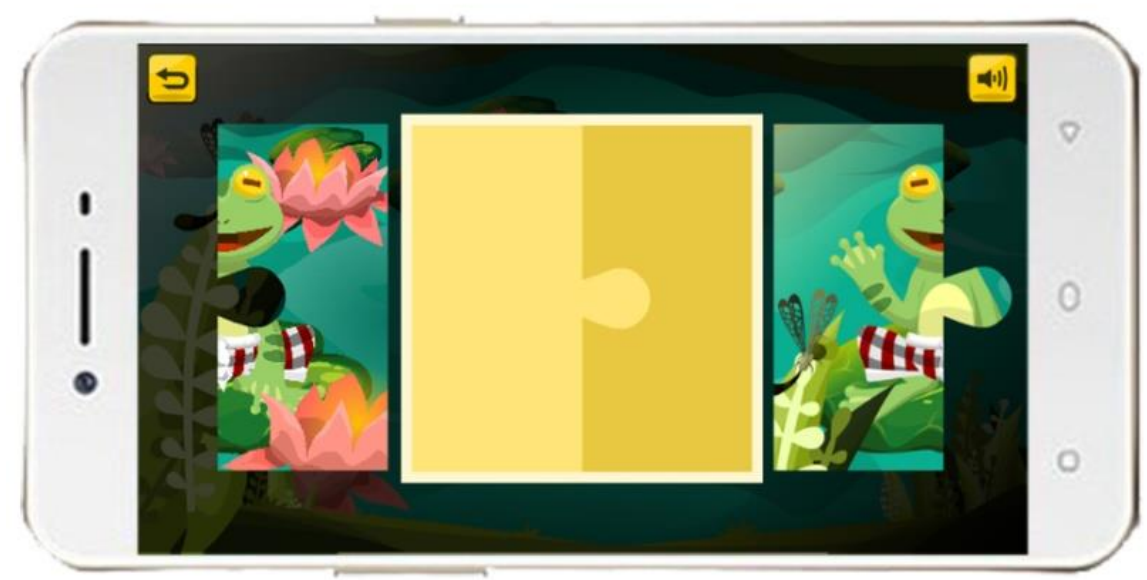

Gambar 8 . Tampilan Permainan Puzzle Tingkat 1

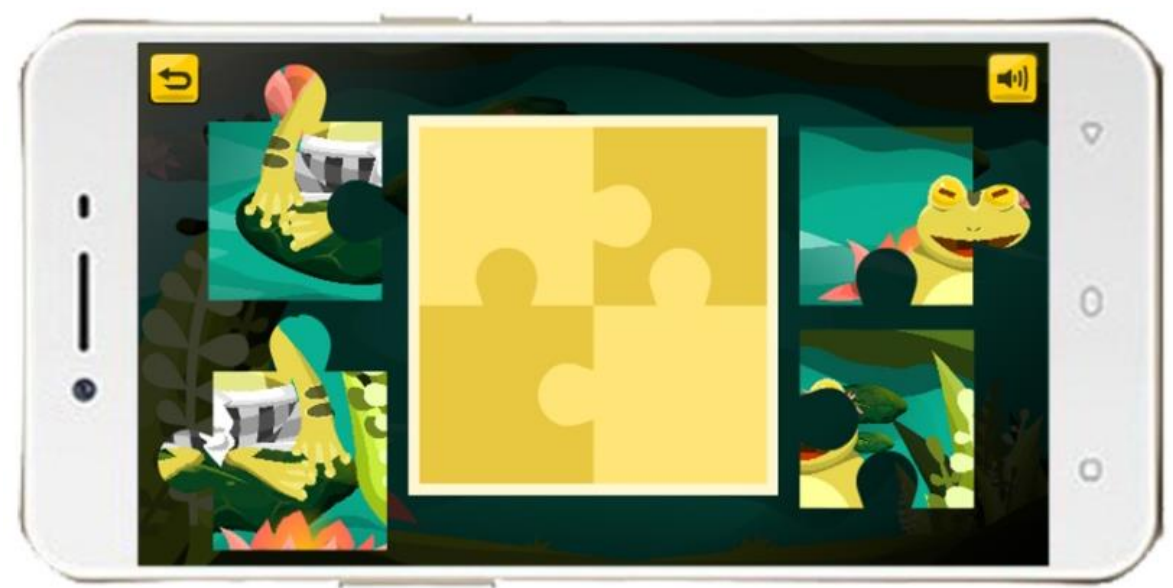

Gambar 9. Tampilan Permainan Puzzle Tingkat 2 


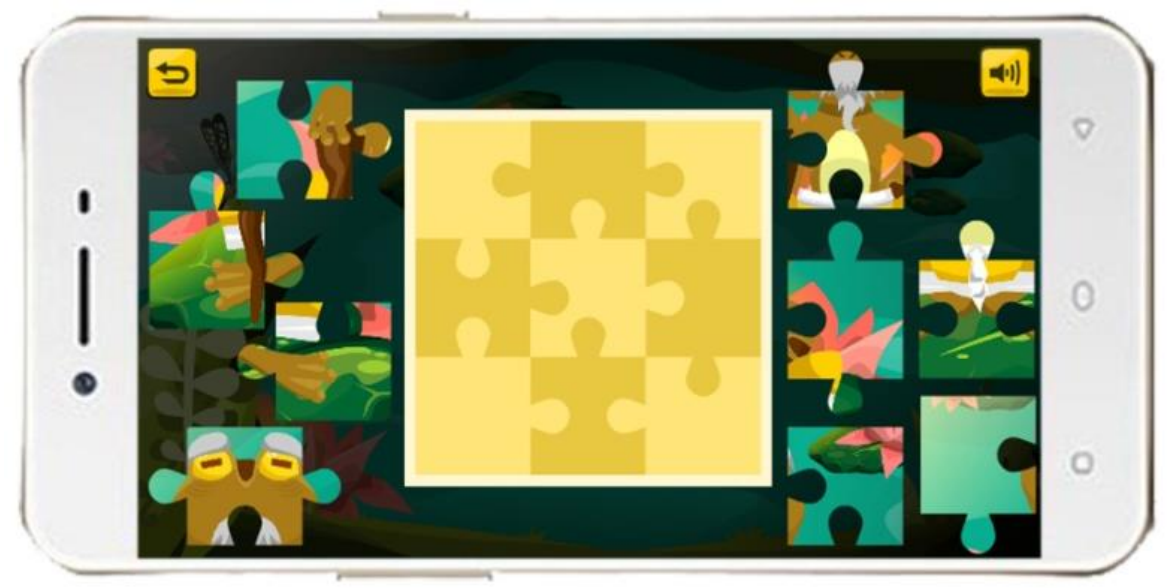

Gambar 10. Tampilan Permainan Puzzle Tingkat 3

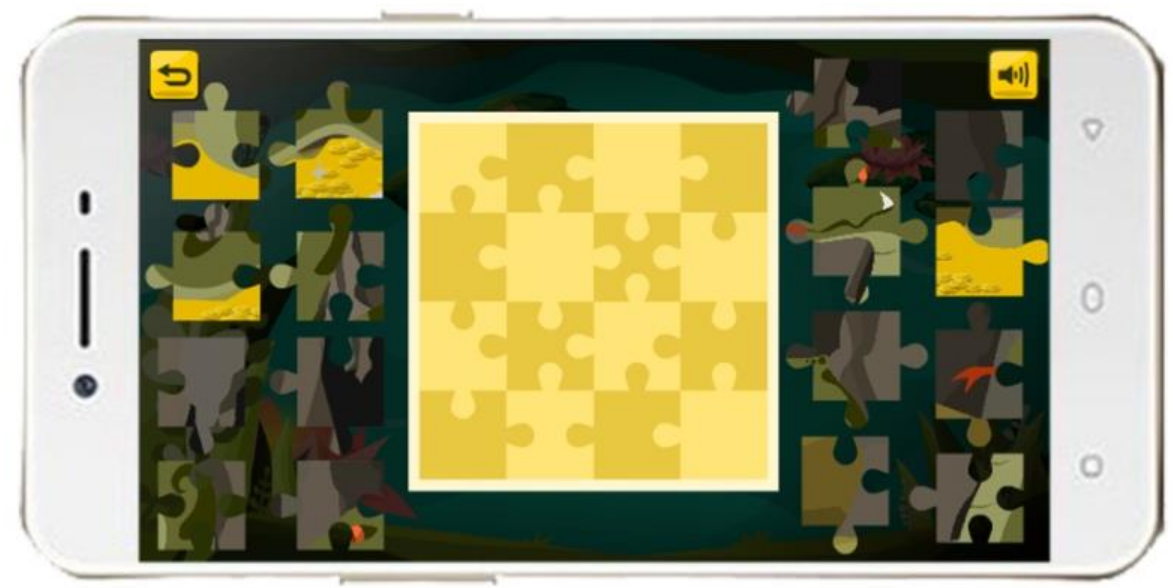

Gambar 11. Tampilan Permainan Puzzle Tingkat 4

Permainan mencari harta karun merupakan permainan berjenis slide scrolling. Pada permainan ini pengguna akan mengumpulkan koin sebanyak-banyak dan menghindari rintangan yang ada. Terdapat dua rintangan pada permainan ini yaitu tebing dan ular. Tampilan permainan mencari harta karun dapat dilihat pada gambar 12 .

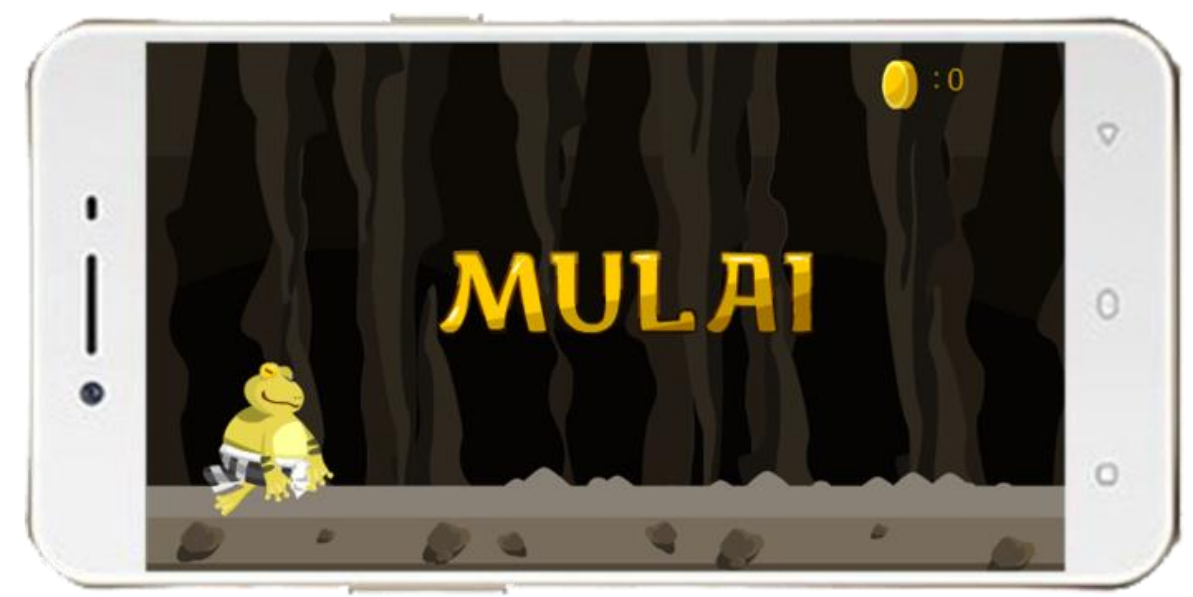

Gambar 12. Tampilan Permainan Mencari Harta Karun 
Pengujian dilakukan kepada 30 responden yang merupakan anak usia 5 sampai 10 tahun menggunakan kuesioner dengan skala likert. Berikut merupakan hasil dari pengujian tersebut:

\begin{tabular}{|c|l|c|}
\hline No & \multicolumn{1}{|c|}{ Pernyataan } & $\begin{array}{c}\text { Tingkat } \\
\text { Persetujuan }\end{array}$ \\
\hline 1 & $\begin{array}{l}\text { Ilustrasi gambar dan warna yang terdapat pada } \\
\text { game menarik }\end{array}$ & $90 \%$ \\
\hline 2 & Animasi yang ditampilkan menarik & $88 \%$ \\
\hline 3 & $\begin{array}{l}\text { Audio dan music yang digunakan jelas dan } \\
\text { menarik }\end{array}$ & $85 \%$ \\
\hline 4 & Teks yang digunakan pada game mudah dibaca & $91 \%$ \\
\hline 5 & Game dan cerita rakyat menarik & $93 \%$ \\
\hline \multicolumn{2}{|c|}{ Rata - rata } & $\mathbf{9 0 \%}$ \\
\hline
\end{tabular}

Tabel 1. Hasil Pengujian

Berdasarkan dari rangkuman tersebut dapat dilihat bahwa rata-rata dari keseluruhan aspek mencapai $90 \%$ atau dapat disimpulkan game Kodok dan Harta Karun ini sangat menarik untuk dimainkan.

\section{Kesimpulan}

Aplikasi game ini dirancang dan dibangun dengan melewati lima tahapan yaitu: merencanakan, menganalisa, merancang, membangun dan menguji. Berdasarkan hasil kuesioner yang telah disebarkan, mayoritas responden menyatakan dari keseluruhan aspek yang diuji, game ini mendapatkan hasil rata-rata $90 \%$ atau dapat disimpulkan game Kodok dan Harta Karun ini sangat menarik untuk dimainkan.

\section{Daftar Pustaka}

[1] I. D. G. A. Pandawana and D. P. Y. Ardiana, "Aplikasi Game Cerita Rakyat Bali Sebagai Sarana Pendidikan Karakter Anak Berbasis Mobile," Lontar Komput. J. Ilm. Teknol. Informasi; Vol. 8, No. 3 Desember 2017DO - 10.24843/LKJITI.2017.v08.i03.p07, Dec. 2017.

[2] M. Taro, Dongeng-dongeng Karmaphala. Denpasar: Amada Press, 2014.

[3] Z. Zulfan et al., "Perancangan Storyboard Konten Animasi 3 Dimensi Untuk Edukasi Anak Usia Sekolah Dasar Tentang Mitigasi Penyebaran COVID-19,” J. Serambi Eng., vol. 7, no. 1, 2022.

[4] Zulfan and Samsuddin, "Analisa \& Perancangan Edukasi Keamanan Berlalu Lintas bagi Masyarakat Berbasis Konten Multimedia Animasi," Anal. Peranc. Edukasi Keamanan Berlalu Lintas bagi Masy. Berbas. Konten Multimed. Animasi, vol. 1, no. 1, pp. 22-30, 2016.

[5] D. P. Y. Ardiana and L. H. Loekito, "Gamification design to improve student motivation on learning object-oriented programming," in Journal of Physics: Conference Series, 2020, vol. 1516, no. 1, p. 12041.

[6] M. D. W. Aristana and D. P. Y. Ardiana, "Gamification design for high school student with unstable internet connection during covid-19 pandemic," J. Phys. Conf. Ser., vol. 1810, no. 1, p. 12057, 2021.

[7] D. P. Y. Ardiana and I. W. D. Suryawan, "Pelestarian Teka-Teki Peribahasa Bali Melalui Game Trivia Cecimpedan Berbasis Mobile,” J. Teknol. Inf. dan Komput., vol. 6, no. 2, pp. 183-194, 2020.

[8] S. A. A. N. Putri, Belajar Membuat Game 2D dan 3D Menggunakan Unity. Sleman: Deepublish, 2017.

[9] R. E. Mayer, Computer Games for Learning: An Evidence-Based Approach. Massachusetts: MIT Press, 2014.

[10] S. K. M. S. M. K. H. S. K. Herlinah, Pemrograman Aplikasi Android dengan Android Studio, Photoshop, dan Audition. Jakarta: Elex Media Komputindo, 2019.

[11] S. Sukri, R. Putra, and W. Yulianti, “Android Based Tire Patch Search,” J. Nas. Komputasi dan Teknol. Inf., vol. 4, no. 6, pp. 425-439, 2021.

[12] Jubilee Enterprise, Mengenal Dasar-Dasar Pemrograman Android. Jakarta: Elex Media Komputindo, 2015. 